\title{
APLIKASI PENGELOLAAN ASET PADA LEMBAGA KEMANUSIAAN PKPU
}

\author{
Raden Ahmad Farhan \\ Program Studi Teknik Informatika, Fakultas Teknik dan Ilmu Komputer, Universitas Indraprasta PGRI \\ TB. Simatupang, Jl. Nangka Raya No.58 C, RT.5/RW.5, Tj. Bar., Kec. Jagakarsa, Kota Jakarta Selatan, \\ Daerah Khusus Ibukota Jakarta 12530 \\ r.ahmadfarhan@gmail.com
}

\begin{abstract}
ABSTRAK
Pada Lembaga Kemanusiaan PKPU yang aktifitasnya dibidang kemanusiaan pasti menggunakan aset dalam setiap kegiatannya. Namun pengelolaannya masih bersifat semi manual dengan mengandalkan program aplikasi umum yakni Microsoft Excel. Hal ini dirasakan kurang efektif karena data yang dicatat tidak terkelola dengan baik. Dengan pemanfaatan teknologi komputer secara tepat, maka dalam menghadapi masalah ini dibutuhkan suatu aplikasi dalam pengelolaan aset. Sehingga diharapkan Lembaga Kemanusiaan PKPU lebih efektif dan efisien dalam pengelolaan aset, pemakaiannya dan perawatannya. Metode penelitian yang digunakan untuk menganalisis aplikasi yang dibuat adalah observasi langsung dan wawancara. Untuk tahap pembuatan aplikasi dimulai dari analisa kebutuhan, perancangan sistem, desain aplikasi dan pengujian. Metode pengembangan yang digunakan yaitu metode waterfall. Tujuan penelitian ini adalah untuk merancang dan membuat aplikasi yang dapat membantu dalam pengelolaan data aset pada Lembaga Kemanusiaan PKPU. Batasan masalah yakni pengelolaan data aset, pengelolaan pemakaian aset, dan pengelolaan perawatan aset. Aplikasi ini menggunakan bahasa pemrograman PHP dan database PostgreSql.
\end{abstract}

Kata Kunci: aplikasi, aset, pkpu, lembaga kemanusiaan, php

\begin{abstract}
In the PKPU Humanitarian Foundation whose activities are in the humanitarian field, they must use assets in each of their activities. However, the management is still semi-manual by relying on a common application program, like Microsoft Excel. This is felt to be less effective because the recorded data is not managed properly. It is not effective because the data didn't well managed. With the proper use of computer technology, in dealing with this problem, an application in asset management is needed. So it is hoped that the PKPU Humanitarian Foundation will be more effective and efficient in asset management. The research method used to analyze the application made is direct observation and interviews. For the application creation stage, starting from requirements analysis, system design, application design and testing. The development method used is the waterfall method. The purpose of this research is to design and create applications that can assist in managing asset data at the PKPU Humanitarian Foundation. The scopes are asset data management, asset use management, and asset maintenance management. This application uses the PHP programming language and the PostgreSql database.
\end{abstract}

Key Word: application, asset, pkpu, humanitarian foundation, php

\section{PENDAHULUAN}

Aset merupakan sumber daya atau kekayaan yang dimiliki oleh suatu entitas lembaga atau perusahaan. Pengelolaan aset oleh lembaga sangat penting apalagi terhadap lembaga kemanusiaan karena terkait akuntabilitas lembaga yang sumber dananya dari masyarakat. Pengelolaan aset ini antara lain pendataan aset, pemakaian aset dan perawatan aset.

Pada Lembaga Kemanusiaan PKPU yang aktifitasnya dibidang penanggulangan bencana, bantuan sosial dan pemberdayaan ini pasti menggunakan aset dalam setiap kegiatannya. Namun pengelolaannya masih bersifat semi manual dengan mengandalkan program aplikasi umum yang merupakan perangkat dari sistem operasi komputer seperti pada Microsoft Window yakni Ms. Office Excel. Hal ini dirasakan kurang efektif karena data yang dicatat tidak tersimpan dengan rapih. Dengan pemanfaatan teknologi komputer secara tepat, manusia dapat menyelesaikan permasalahannya dengan efektif dan efisien. Maka dari itu, dalam menghadapi masalah ini dibutuhkan suatu aplikasi dalam pengelolaan aset. Sehingga diharapkan Lembaga Kemanusiaan PKPU 
lebih efektif dan efisien dalam pendataan aset, pemakaiannya dan perawatannya.

Berdasarkan uraian di atas, maka penulis melakukan penelitian dengan judul Aplikasi Pengeloaan Aset Pada Lembaga Kemanusiaan PKPU

Tujuan utama penelitian ini adalah untuk merancang dan membuat aplikasi yang dapat membantu dalam pengelolaan data aset pada Lembaga Kemanusiaan PKPU. Manfaat penelitian ini adalah untuk menambah wawasan dan kemampuan berpikir mengenai penerapan teori yang telah didapat dari mata kuliah yang telah diterima ke dalam penelitian yang sebenarnya. Selain itu, untuk memberikan solusi terhadap masalah yang dihadapi dalam pengelolaan aset pada Lembaga Kemanusiaan PKPU.

\section{METODE PENELITIAN}

Waktu yang digunakan untuk penelitian ini dilaksanakan sejak bulan Oktober 2019 dalam kurun waktu kurang lebih empat bulan, yakni satu bulan pengumpulan data dan tiga bulan untuk perancangan dan pembuatan aplikasi. Tempat pelaksanaan penelitian ini adalah di Lembaga Kemanusiaan PKPU di Jalan Anggrek no 97 Kelurahan Cisalak Kecamatan Cimanggis Kota Depok Jawa Barat.

Metode pengumpulan data yaitu dengan cara observasi, wawancara, dan studi literatur. Dalam penelitian ini akan digunakan metode pendekatan waterfall. Langkah-langkah dalam penelitian ini yakni wawancara kepada user, menganalisa sistem yang berjalan, merancang sistem yang diusulkan, mengimplementasikan rancangan yang dibuat dalam bentuk kode program, melakukan uji coba aplikasi yang telah dibangun, kemudian melakukan perbaikan dan perawatan sistem.

\section{HASIL DAN PEMBAHASAN}

Diagram Alir Data (DAD) pada sistem yang diusulkan yakni :

\section{Diagram Konteks}

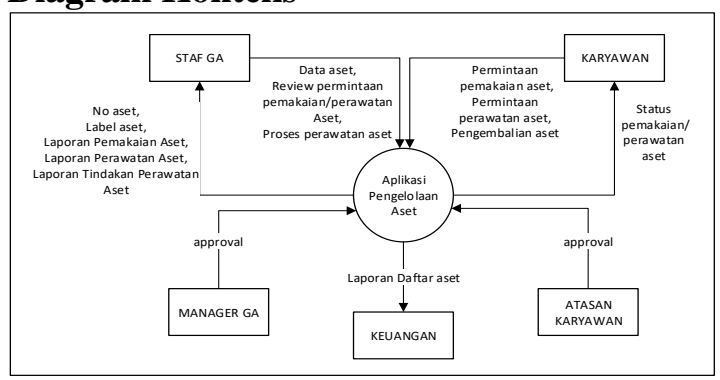

Gambar 1. Diagram Konteks
Keterangan :

Pada Aplikasi Pengelolaan Aset Lembaga Kemanusiaan PKPU ini entitas yang terlibat adalah dari divisi General Affair (GA) sebagai divisi yang mempunyai kewajiban mengelola aset yakni Staf GA dan Manager GA, kemudian dari pengguna aset yakni Karyawan dan Atasannya. Serta dari divisi Keuangan yang membutuhkan laporan daftar aset sebagai bahan untuk proses akuntansi keuangan lembaga.

\section{Diagram Nol}

Diagram ini merupakan dekomposisi dari level sebelumnya. Proses dekomposisi dilakukan hingga proses siap dituangkan ke dalam program.

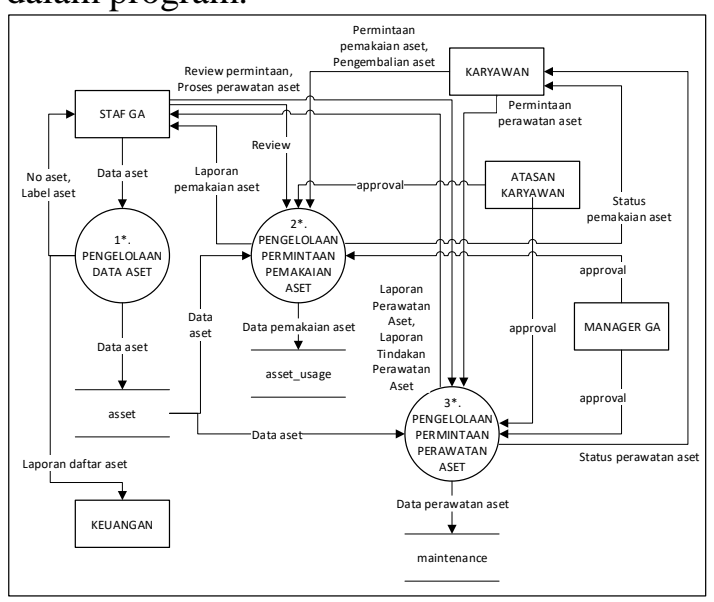

Gambar 2. Diagram Nol

Keterangan :

Staf GA melakukan pengelolaan aset yang terbagi dalam beberapa proses diantaranya:

Proses 1. Pengelolaan Data Aset

Proses ini Staf GA mengelola data aset yakni bisa menginput, mengedit, atau menghapus data aset. Data aset tersebut akan disimpan pada database/penyimpanan data "asset". Selanjutnya output pada proses ini adalah nomor aset dan label aset untuk kebutuhan Staf GA, serta laporan daftar aset yang akan dibutuhkan oleh Divisi Keuangan sebagai bahan dalam proses akuntansi keuangan lembaga.

Proses 2. Pengelolaan Permintaan Pemakaian Aset

Proses ini Karyawan mengajukan permintaan pemakaian aset yang telah disetujui oleh Atasannya. Selanjutnya akan direview oleh Staf GA dan ada proses approval oleh Manager GA. Data pemakaian aset ini akan disimpan pada penyimpanan data 
“asset_usage". Selanjutnya output dari proses ini adalah Laporan Permintaan Pemakaian Aset

Proses 3. Pengelolaan Permintaan Perawatan Aset

Apabila ada kerusakan atau perawatan rutin pada aset maka akan dilakukan proses pengelolaan permintaan perawatan aset yang diawali dari permintaan perawatan aset oleh Karyawan pemakai aset yang telah disetujui oleh Atasannya. Selanjutnya akan direview oleh Staf GA dan ada proses approval oleh Manager GA. Data perawatan aset ini akan disimpan pada penyimpanan data maintenance.

\section{Diagram Rinci}

Diagram Rinci Level 1 Proses 1. Pengelolaan Data Aset



Gambar 3. DAD Rinci Proses 1. Pengelolaan Data Aset

Keterangan :

Proses pengelolaan data aset yang dilakukan oleh Staf GA ini berawal dari mengelola jenis aset. Proses tersebut akan disimpan pada penyimpanan data "asset_type".

Kemudian proses mengelola kategori aset, pada setiap jenis aset tadi terdapat beberapa kategori aset yang disimpan pada penyimpanan data "asset_category".

Selanjutnya proses mengelola data aset berdasarkan kategori aset yang telah diinput sebelumnya, disimpan pada penyimpanan data "asset" yang kemudian outputnya akan digunakan pada proses mencetak label aset.

Data aset ini juga dapat diekspor ke dalam format PDF sebagai laporan daftar aset yang akan digunakan oleh Keuangan sebagai bahan dalam proses akuntansi keuangan lembaga.

Diagram Rinci Level 1 Proses 2. Pengelolaan Permintaan Pemakaian Aset

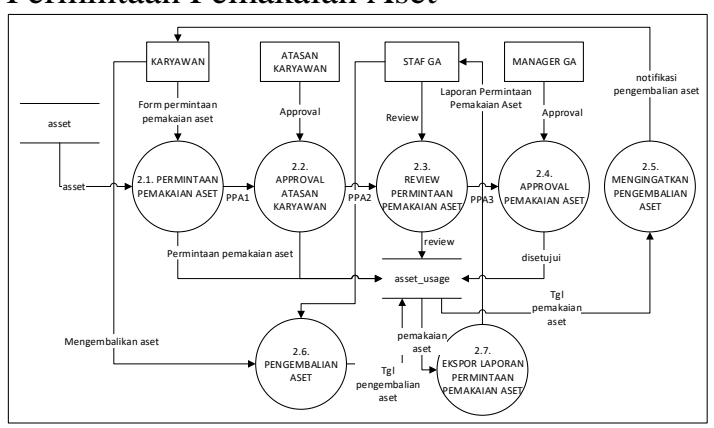

Gambar 4. DAD Rinci Proses 2. Pengelolaan Permintaan Pemakaian Aset

Keterangan :

Proses permintaan pemakaian aset dimulai dari Karyawan menginput form permintaan pemakaian aset yang data asetnya diambil dari penyimpanan data "asset". Kemudian Atasan Karyawan pengaju melakukan proses approval permintaan tersebut. Selanjutnya Staf GA melakukan proses review permintaan pemakaian aset, dan Manager GA melakukan proses approval pemakaian aset. Ketika sudah mendekati akhir waktu pemakaian aset, maka sistem akan mengingatkan dengan mengirimkan notif pengembalian aset kepada Karyawan pengaju. Setelah jangka waktu pemakaian aset habis maka dilakukan proses Pengembalian Aset. Semua data pemakaian aset ini tersimpan di dalam penyimpanan data "asset_usage". Untuk kebutuhan laporan, Staf GA dapat mengekspor Laporan Permintaan Pemakaian Aset dalam format PDF.

Diagram Rinci Level 1 Proses 3. Pengelolaan Permintaan Perawatan Aset

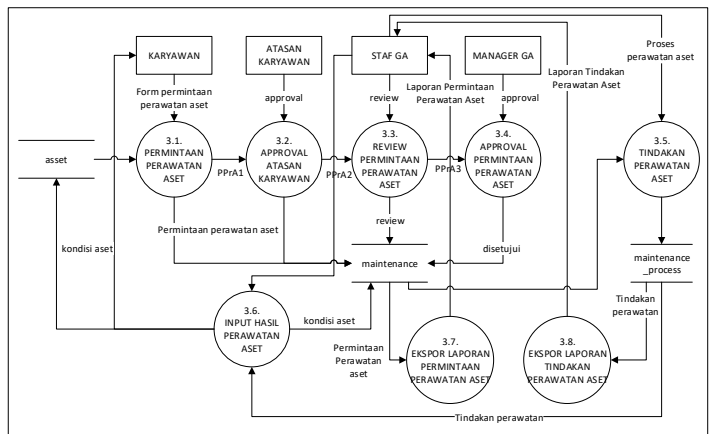

Gambar 5. DAD Rinci Proses 3. Pengelolaan Permintaan Perawatan Aset 
Keterangan :

Proses permintaan perawatan aset dimulai dari Karyawan menginput form permintaan perawatan aset yang data asetnya diambil dari penyimpanan data "asset". Kemudian Atasan Karyawan pengaju melakukan proses approval permintaan tersebut. Selanjutnya Staf GA melakukan proses review permintaan perawatan aset, dan Manager GA melakukan proses approval permintaan perawatan aset. Semua data permintaan perawatan aset ini tersimpan di dalam penyimpanan data "maintenance".

Kemudian Staf GA melakukan proses Tindakan Perawatan Aset yakni Staf GA merencanakan apa yang perlu dilakukan dalam tindakan perawatan aset. Kemudian melaksanakan tindakan tersebut sampai semua tindakan perawatan aset dilakukan. Tindakan perawatan aset ini disimpan pada penyimpanan data "maintenance_process". Kemudian proses Input Hasil Perawatan Aset yang telah dilakukan oleh Staf GA ke dalam aplikasi. Apakah kondisi aset menjadi baik dan bisa digunakan seperti sedia kala atau kondisi rusak sehingga aset tidak dapat digunakan kembali. Kemudian dari aplikasi akan memberikan notifikasi informasi hasil perawatan aset kepada karyawan yang mengajukan permintaan perawatan aset. Selain itu data kondisi aset juga akan diperbarui yang disimpan pada penyimpanan data "asset".

Untuk kebutuhan laporan, Staf GA dapat melakukan proses Ekspor Laporan Permintaan Perawatan Aset dan Ekspor Laporan Tindakan Perawatan Aset dalam format PDF sesuai dengan template yang telah ditentukan.

\section{Tampilan Layar}

1. Tampilan Login

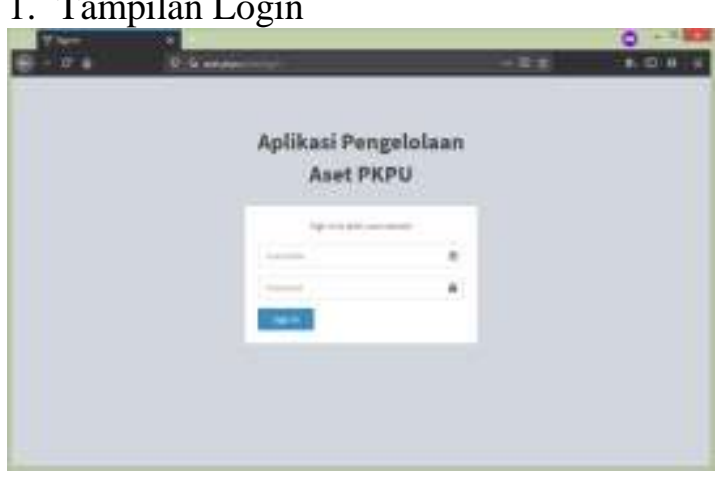

Gambar 6. Login
Setiap karyawan mempunyai username dan password masing-masing yang dapat digunakan untuk Sign in pada halaman Login di atas.

\section{Tampilan Menu Aset}

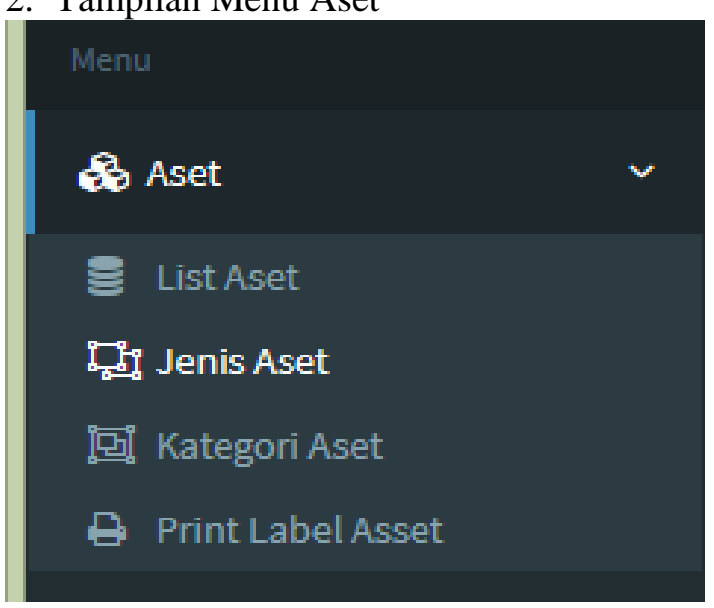

Gambar 7. Menu Aset

Seperti Gambar 7 di atas, pada menu Aset terdapat submenu berikut :

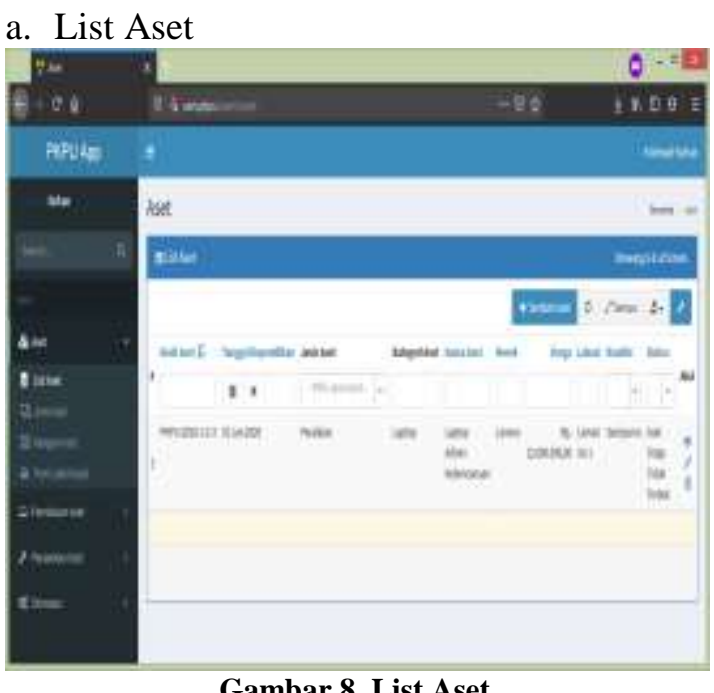

Gambar 8. List Aset

Untuk menambah data aset maka klik tombol Tambah Aset, maka akan muncul dialog form aset. Isi form tersebut kemudian klik Save. 


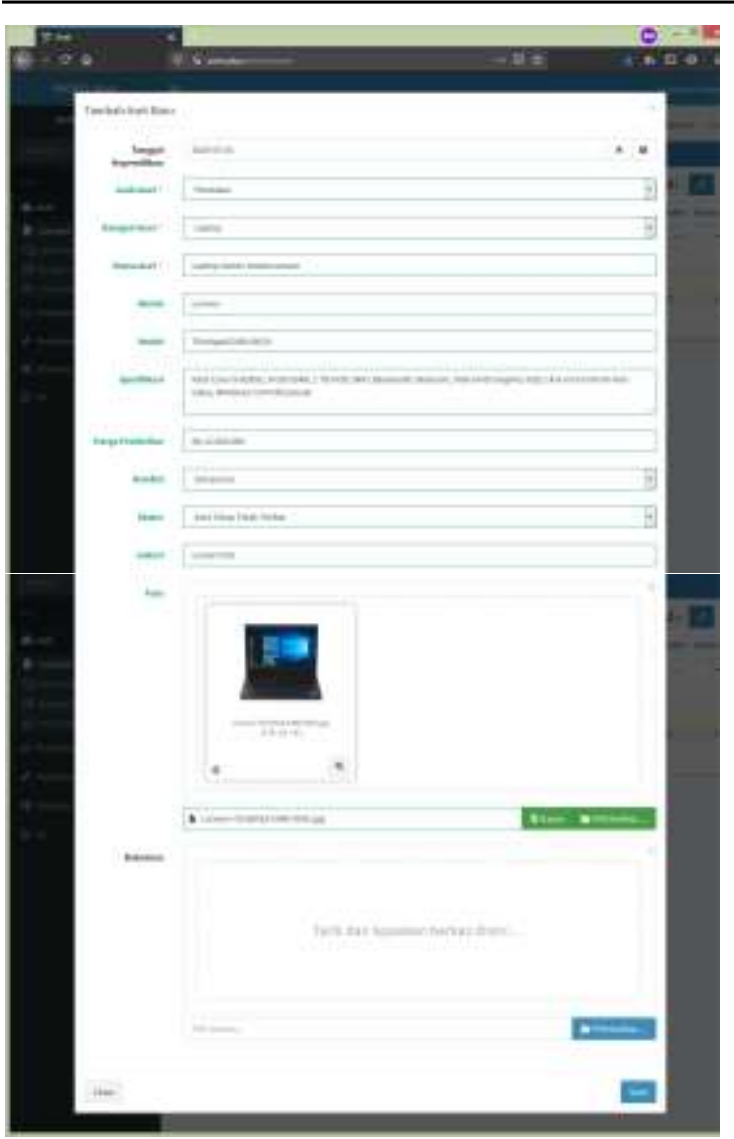

Gambar 9. Form Aset

Apabila sukses tersimpan, maka akan muncul halaman View Detail Aset seperti berikut :

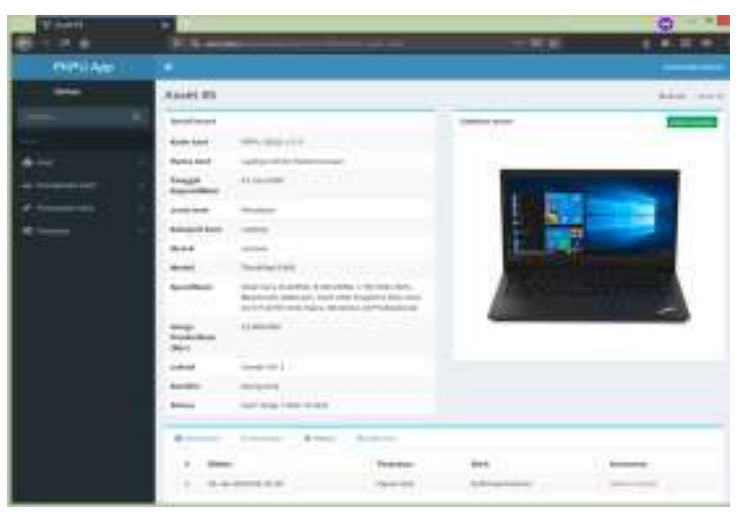

Gambar 10. View Detail Aset

b. Jenis Aset

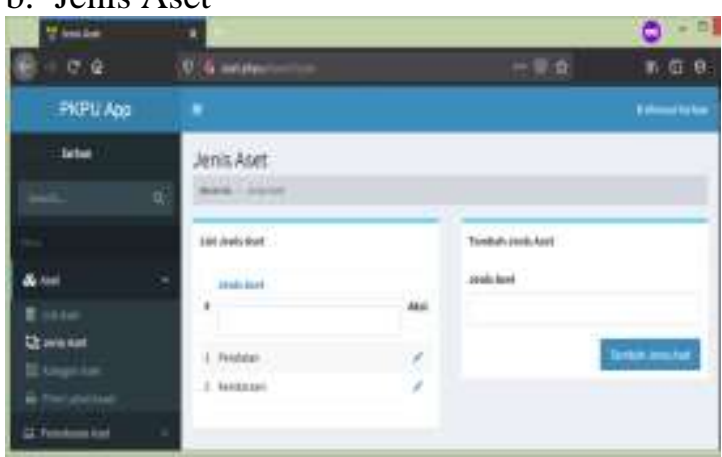

Gambar 11. Jenis Aset
Untuk menambahkan jenis aset maka isi di form sebelah kanan kemudian klik tombol Tambah Jenis Aset.

\section{c. Kategori Aset}

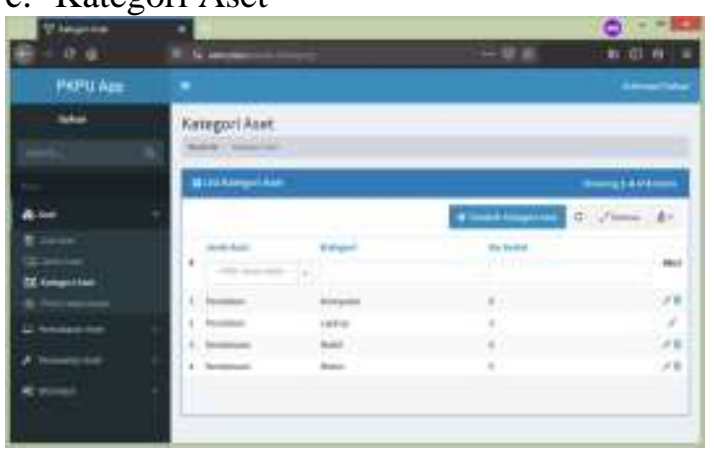

Gambar 12. Kategori Aset

Untuk menambahkan kategori aset, klik tombol Tambah Kategori Aset maka akan muncul form berikut :

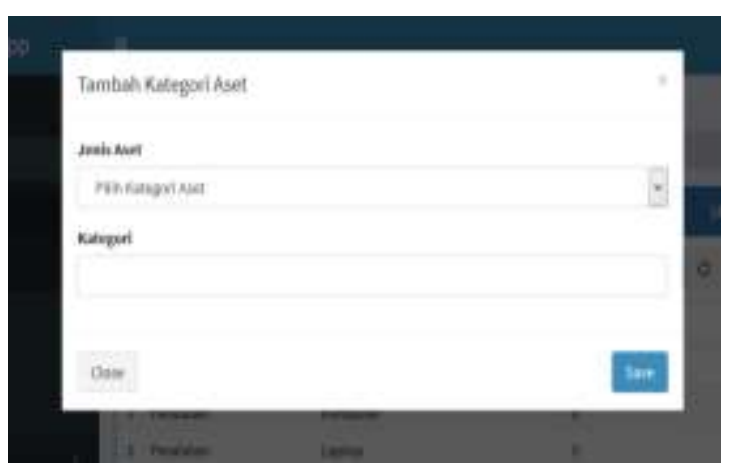

Gambar 13. Form Kategori Aset

Klik Save untuk menyimpan.

d. Print Label Aset

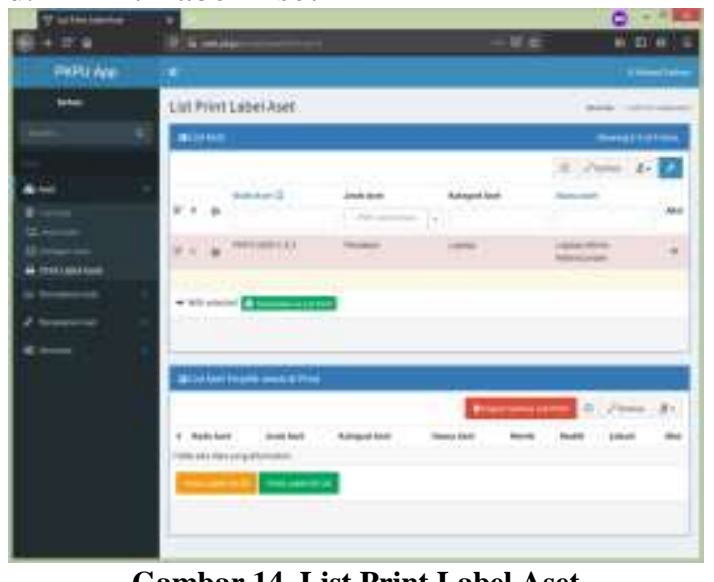

Gambar 14. List Print Label Aset

Checklist aset yang akan diprint labelnya, kemudian klik tombol Tambahkan ke List Print. Maka data aset yang dichecklist tadi akan masuk ke tabel dibawahnya, seperti berikut : 




Gambar 15. Print Label

Kemudian klik tombol Print Label UK 36 (untuk ukuran label 36) atau Print Label UK 24 (untuk ukuran label 24). Maka outputnya seperti berikut :

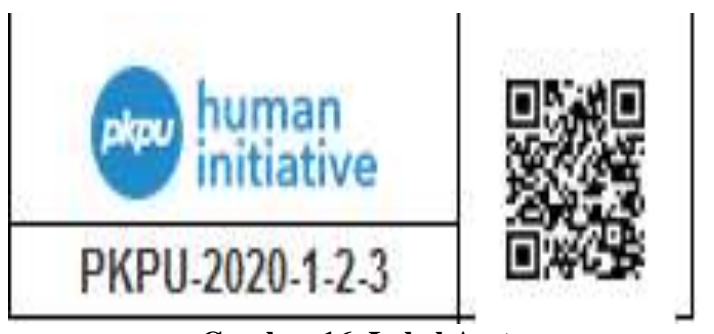

Gambar 16. Label Aset

3. Tampilan Menu Pemakaian Aset

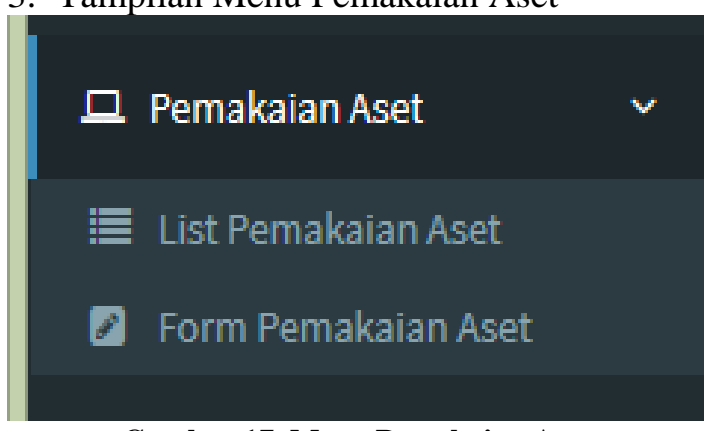

Gambar 17. Menu Pemakaian Aset

Klik List Pemakaian Aset untuk melihat daftar pengajuan pemakaian aset sebagai berikut :

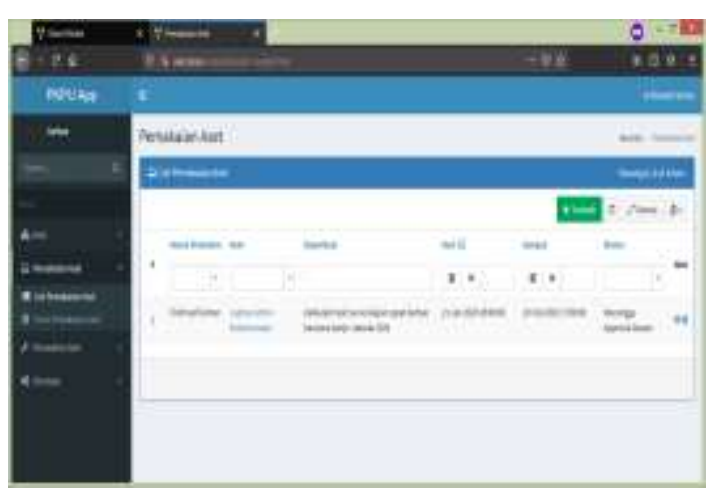

Gambar 18. List Pemakaian Aset
Klik submenu Form Pemakaian Aset untuk mengajukan Permintaan Pemakaian Aset seperti berikut :

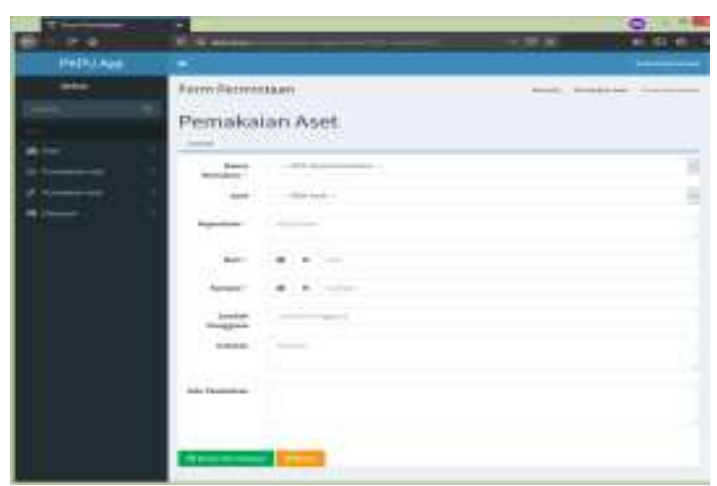

Gambar 19 Form Permintaan Pemakaian Aset

Klik tombol Kirim Permintaan untuk proses selanjutnya.

4. Tampilan Menu Perawatan Aset

Klik menu List Perawatan Aset untuk melihat data permintaan perawatan aset seperti berikut:



Klik Form Perawatan Aset untuk mengajukan Permintaan Perawatan Aset seperti berikut :

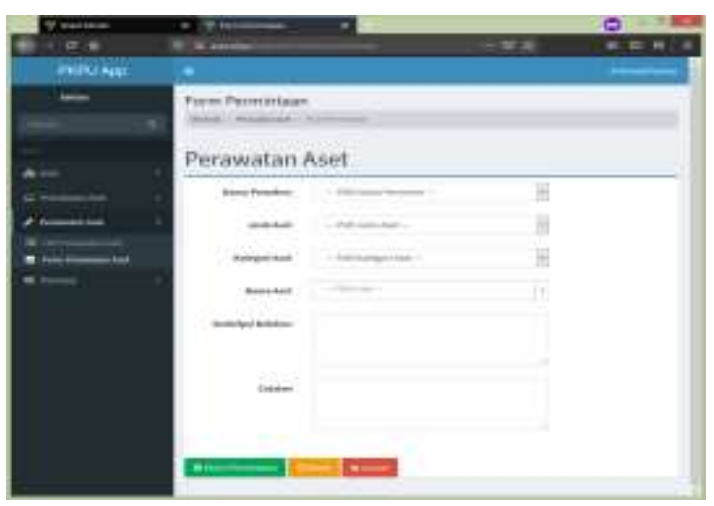

Gambar 21. Form Perawatan Aset

Klik Kirim Permintaan untuk proses selanjutnya. 
5. Tampilan review Staf GA

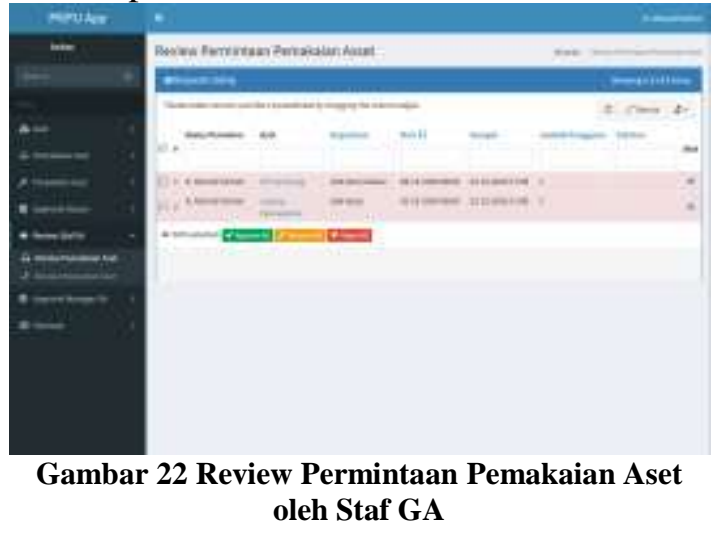

Klik checklist pada bagian yang akan diproses, kemudian klik tombol Approve All untuk proses disetujui, atau tombol Revision All untuk proses direvisi, atau tombol Reject All untuk proses ditolak.

\section{Tampilan approval Manager GA}

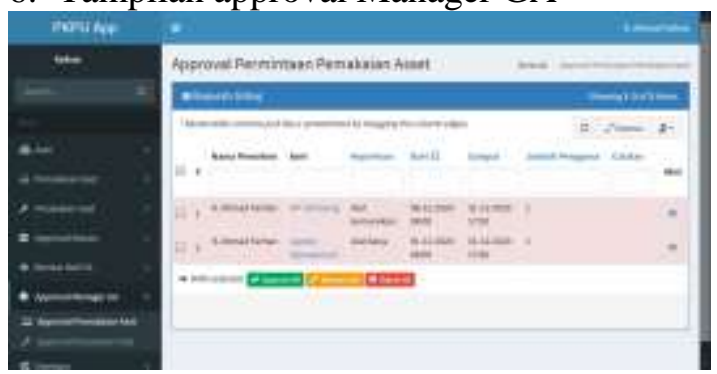

Gambar 23 Approval Permintaan Pemakaian Aset oleh Manager GA

Klik checklist pada bagian yang akan diproses, kemudian klik tombol Approve All untuk proses disetujui, atau tombol Revision All untuk proses direvisi, atau tombol Reject All untuk proses ditolak.

\section{Laporan}

Laporan dapat diekspor dalam format pdf dari aplikasi. Output laporannya seperti berikut :

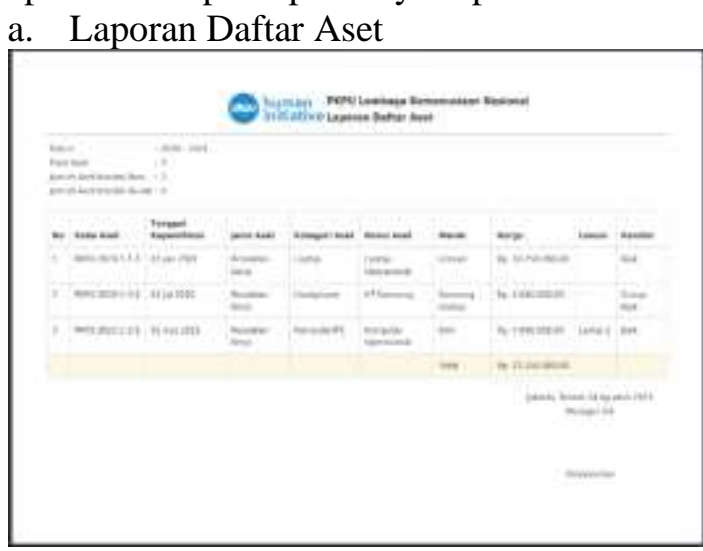

Gambar 24. Laporan Daftar Aset b. Laporan Permintaan Pemakaian Aset



Gambar 25. Laporan Permintaan Pemakaian Aset

c. Laporan Permintaan Perawatan Aset

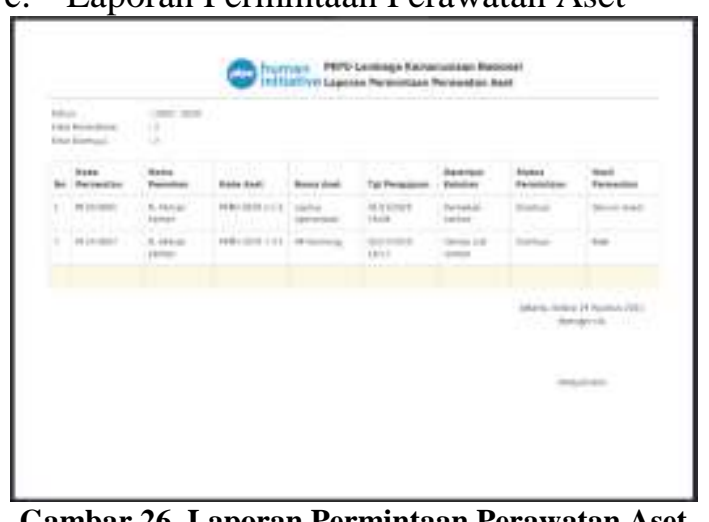

Gambar 26. Laporan Permintaan Perawatan Aset

d. Laporan Tindakan Perawatan Aset

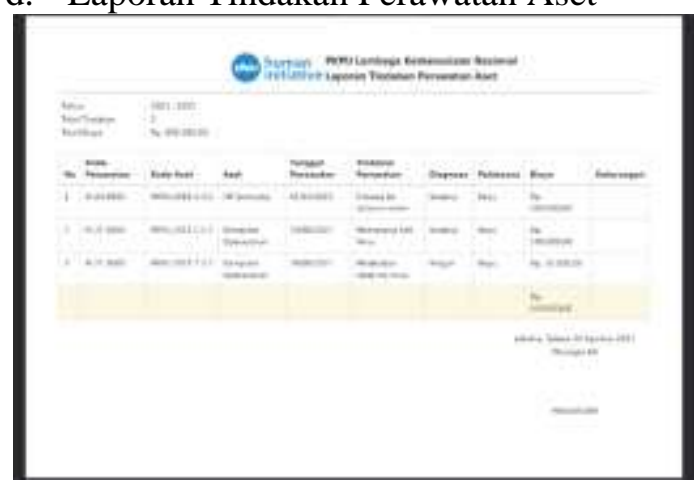

Gambar 27. Laporan Tindakan Perawatan Aset

\section{SIMPULAN DAN SARAN}

Aplikasi Pengelolaan Aset pada Lembaga Kemanusiaan PKPU ini meliputi dari database aset, pengelolaan pemakaian aset, dan pengelolaan perawatan aset.

Aplikasi Pengelolaan aset ini diakses secara online dengan menggunakan Bahasa pemrograman PHP dan database PostgreSql. Dengan data aset yang terpusat dan dikelola dengan aplikasi agar pengelolaan aset dapat dilakukan secara efektif dan efisien

Aplikasi pengelolaan aset ini juga dapat mencetak label aset yang didalamnya terdapat QR code yang dapat dipindai untuk 
ditampilkan detail datanya di aplikasi. Hal ini diharapkan dapat dengan mudah menelusuri aset yang sudah terdata.

Saran untuk penelitian selanjutnya diantaranya menambahkan modul penyusutan aset. Selain itu Aplikasi pengelolaan aset ini dapat juga dikembangkan untuk versi mobile sehingga memberikan fleksibilitas dalam pemakaiannya.

\section{DAFTAR PUSTAKA}

Andriani, A. (2016). Manajemen basis data : pemodelan, perancangan dan penerapan. Yogyakarta: Deepublish.

Aryandi, I. (2019). Perancangan Aplikasi Data Aset Perusahaan Pada BRI Corporate University Berbasis Java. Skripsi Tidak Diterbitkan. Jakarta: Universitas Indraprasta PGRI.

Kadir, A. (2009). From Zero to Pro:Membuat Aplikasi Web dengan PHP dan Database MySQL. Yogyakarta: Andi.

Kristanto, A. (2018). Perancangan Sistem Informasi dan Aplikasinya. Yogyakarta: Gava Media.

Pambudi, G. S. (2016). Rancang Bangun Sistem Manajemen Aset Berbasis Web. Skripsi Tidak Diterbitkan. Semarang: Universitas Diponegoro.

Prawiro, M. (12 Januari 2018). Pengertian Aset Dalam Akuntansi, Jenis-Jenis Aset, Siklus, Perencanaan dan Penggunaan Aset. Diambil 11 Oktober, 2019,

https://www.maxmanroe.com/vid/finan sial/akuntansi/pengertian-aset.html

Rizki, A. (2019). Analisis dengan Diagram Keterhubungan Entitas (Entity Relationship Diagram / ERD). Diambil 11 Oktober, 2019, http://www.scribd.com/doc/39104876/I $\mathrm{X}$-ERD

Sarosa, S. (2017). Metodologi Pengembangan Sistem Informasi. Jakarta: Indeks.

Sidik, B. (2017). Pemrograman Web dengan PHP 7. Bandung: Informatika.

Sulistyo Nugroho, A. (2017). Analisis dan Perancangan Sistem Informasi. Yogyakarta: Trans Tekno. 